\title{
THE RISK FACTORS OF DENGUE HEMORRHAGIC FEVER (DHF) CASES IN PEKANBARU
}

\author{
Herlina Susmaneli ${ }^{1}$, Dedi Afandi ${ }^{2}$, Zahtamal ${ }^{2}$, Rasoel Hamidy ${ }^{3}$ and Zulfan Saam ${ }^{3}$ \\ ${ }^{1}$ Public Health Degree Study Program of Hang Tuah School of Health Science Pekanbaru. \\ ${ }^{2}$ Medical Faculty of Riau University. \\ ${ }^{3}$ Environmental Study, Graduate Program of Riau University.
}

Corresponding author: Herlina Susmaneli

Email: susmaneliherlina@gmail.com

\begin{abstract}
Pekanbaru is one of the cities in Riau Province which is an endemic area for Dengue Hemorrhagic Fever (DHF) with the Incidence Rate exceeding the endemic limit of 148,80 per 100.000 population. The purpose of this research was to determine the influence of the distance between houses, water storage condition, the existence of garbage, the existence of larvae around the houses. To determine attitude, knowledge, eradication of mosquito nests, the morning and or afternoon sleep habits, the habit of hanging clothes, and the existence of ornamental plants on Dengue Hemorrhagic Fever (DHF) cases. The type of research was observational quantitative analytic with a Case-Control design. The sampling technique used was Non-Probability Sampling and multivariate analysis used is multiple logistic regression. The sample was 138 respondents and Primary data collection using questionnaires and observation sheets. Six variables affecting the DHF cases were the existence of larvae $(O R=8.103)$, eradication of mosquito nests $(O R=6.230)$, water storage conditions $(O R=2.136)$, the sleep habits in the morning and or afternoon $(O R=2.058)$, the existence of garbage $(O R=0.233)$ dan knowledge $(O R=0.165)$. This suggests that the community can do eradicate mosquito nets. . Eradicating mosquito nests can be carried out through $3 \mathrm{M}$ Plus activities, including regularly draining the bathtub at least once a week, changing the water in flower vases, bird drinking places, or other water reservoirs regularly every less than one week. Closing water reservoirs tightly. Utilizing / recycling used cans, plastics, used tires, and other items that can hold rainwater so that they do not become mosquito breeding grounds. Six variables that influence the DHF cases, were: the existence of larvae, the action of $3 \mathrm{M}$ Plus, the condition of the water reservoir, the habit of sleeping in the morning and afternoon, the existence of garbage, and knowledge. Four variables did not affect the DHF cases, they were: attitude, the distance among houses, the habit of hanging clothes, and the existence of yard/ornamental plants. The community is expected to be able to recycle waste (garbage that has the potential to hold water).
\end{abstract}

Keywords: DHF, the existence of larvae, endemic limit

\section{INTRODUCTION}

Dengue Hemorrhagic Fever (DHF) is a contagious disease caused by the dengue virus and transmitted by Aedes Aegypti mosquitoes, which is characterized by sudden fever 2 to 7 days without apparent cause, weakness/fatigue, anxiety, heartburn, accompanied by signs of bleeding on the skin in the form of bleeding spots (petechiae, bruising (ecchymosis) or rash (purpura), sometimes nosebleeds, bloody feces, decreased consciousness or shock (Ministry of Health Republic of Indonesia, 2011).

Nowadays, Dengue Hemorrhagic Fever (DHF) is still a health problem in Riau Province which requires serious attention from all sides, considering that this disease has the potential to occur in Extraordinary Cases and is a threat for communities. In Riau Province, the number of DHF cases reported in 2014 was 2.342 cases of DHF sufferers and 31 people died (IR 36,83 per 100.000 population, $C F R=1,32 \%$ ), DHF sufferers were 1.712 cases in 2015 and those with 7 people died (CFR $=0,49 \%$ ) and DHF sufferers increased by more than $50 \%$ to 4.170 cases in 2016 and 39 people died
(CFR $=0,9 \%$ ) (Health Office of Riau Province, 2017).

Based on the data from Pekanbaru Health Office in 2017, the highest DHF case was at Harapan Raya public health center working area which had 98 cases with IR148,80 per 100.000 population and the lowest DHF case was at Simpang Baru public health center with IR 21,80 per 100.000 population (Health Office of Pekanbaru, 2017).

Some factors are causing DHF disease, are house environment (house distance, house layout, container existence, altitude and climate, biological environment (ornamental plants, garden plants that affect humidity, lack of home lighting and larvae eating fish) and social environment (habit of hanging clothes, the habit of napping, habit of cleaning water reservoirs, habit of cleaning yard, community participation in cleaning mosquito nests) (Prasetyani, 2015). Besides, the lack of an effective mosquito control system and the weakness of public health also affect the transmission of DHF (Ministry of Health Republic of Indonesia, 2011). 
Eradicating mosquito nests can be carried out through $3 \mathrm{M}$ Plus activities, including Regularly draining the bathtub at least once a week, changing the water in flower vases, bird drinking places, or other water reservoirs regularly every less than one week. Closing water reservoirs tightly. Utilizing / recycling used cans, plastics, used tires, and other items that can hold rainwater so that they do not become mosquito breeding grounds (Susanto, 2007).

The government already has a regulation regarding the eradication of mosquito nests with $3 M$ Plus by doing activities such as one Jumantik (larvae monitoring people) in one house, which is Circular Letter Number PM.01.11/MENKES/591/2016. 3M Plus means to drain water reservoirs, close the potential water reservoirs into the breeding nest for mosquitoes, recycle or reuse the used items that can hold water, water reservoirs such as tub, pond, the vase that can hold water. Conceptually, Eradication of Mosquito Nests (PSN) action by doing $3 \mathrm{M}$ Plus once in a week is satisfying enough to cut the mosquito's life cycle. (Ministry of Health Republic of Indonesia,2016). The study aims to analyze the factors related to DHF cases at Harapan Raya Public Health Center in Pekanbaru.

\section{METHODS}

The type of this research is qualitative research with an observational analytic study by using a case-control design. The location of this study was carried out in the working area of the Harapan Raya Public Health Center in 2018. The study lasted for 8 months, from April to December 2018. The case population used in this study was all people who suffered from DHF in the working area of Harapan Raya Public Health Center in 2017, a total of 98 people were recorded in the DHF register book started from January to December 2017. The control population used in this study was all people who did not suffer from DHF in the working area of Harapan Raya Public Health Center in 2017. The sample of cases in this study were some people who suffered from DHF in the working area of Harapan Raya Public Health Center started from January until December 2017. This control sample as many people who did not suffer from DHF disease and was neighboring cases in the working area at Harapan Raya Public Health Center in 2017.

The sampling technique used is Nonprobability Sampling, namely by Quota Sampling where quota sampling is carried out by determining the number of sample members by quotum or quota. This sampling technique is done by first determining how much sample is needed or determining the quotum (quota). Then the number or quotum is used as the basis for taking the required sample units. Whichever population member to be taken does not matter, as long as the number of quotums that has been determined can be met.
The number of samples was obtained using the Lameshow (1997), the formula for casecontrol design i.e; $\mathrm{n}=\frac{\left(\mathrm{Z}_{1-\alpha / 2} \sqrt{2} \mathrm{P}(1-\mathrm{P})+\mathrm{Z}_{1-\beta} \sqrt{ } \mathrm{P}_{1}\left(1-\mathrm{P}_{1}\right)+\mathrm{P}_{2}\left(1-\mathrm{P}_{2}\right)^{2}\right.}{\left(\mathrm{P}_{1}-\mathrm{P}_{2}\right)^{2}}$

$\mathrm{n}=$ number of samples

$a=5 \%(0,05)$

$\mathrm{Z}_{1-\mathrm{a} / 2}=\mathrm{Z}$ distribution at the level of significance (a) in the 2-tailed test (1.96)

$Z_{1-B}=Z$ distribution on the strength of the power test $(B)$ on the 2 -tailed test (1.28)

$\mathrm{P}_{1} \quad=$ proportion of certain risk factors in the group suffering from dengue in previous studies.

P2 = the proportion of certain risk factors in the group that did not suffer from dengue in previous studies, namely doing $3 \mathrm{M}$ Plus $(0.51)$

$P=\left(P_{1}+P_{2}\right) / 2$

Based on the calculation of Odds Ratio (OR) and $\mathrm{P}_{2}$, Lemeshow formula manually obtained a sample of 69 people, by using a ratio of $1: 1$, the sample of control was 69 people so that the total sample was 138 people.

The data collection was carried out by interview using a questionnaire to find out the risk factors under study given to respondents, both respondents of case and control, direct observation or field observation carefully and accurately at the location of the study by using the checklist. statistical analysis by using multiple logistic regression tests with a predictive model. The steps that must be taken in the analysis are: first, bivariate selection, that is, for each independent variable a bivariate analysis is carried out with the dependent variable. If the bivariate results produce a $p$-value $<0.25$, then the variable is said to be a candidate and goes straight to the multivariate stage. For independent variables whose bivariate results are $\geq 0.25$, the variable is said to be not a candidate and does not enter the multivariate stage, but if it is important, then the variable can be included in the multivariate model, both multivariate modeling and confounding checks if a change in value is obtained. OR before and after being issued is more than $10 \%$, then the variable is a confounding variable and the three interaction tests are carried out on variables that are suspected of having an interaction if there is no interaction test.

\section{RESULTS}

Respondent Characteristic

The community characteristics in the working area of Harapan Raya Public Health Center who became the respondents in this study were gender, level of education, and occupation, as shown in table1. The distribution of the risk factors based on DHF cases can be seen in the following table 2 . 
Table 1: The Respondent Characteristics in the Working Area of Harapan Raya Public Health Center Pekanbaru in 2018

\begin{tabular}{|c|c|c|c|c|}
\hline No. & $\begin{array}{l}\text { Respondent } \\
\text { Characteristic }\end{array}$ & Category & Frequency & $\%$ \\
\hline \multirow[t]{2}{*}{1} & Gender & Male & 27 & 19,6 \\
\hline & & Female & 111 & 80,4 \\
\hline \multirow[t]{2}{*}{2} & Education & High & 110 & 79,7 \\
\hline & & Low & 28 & 20,3 \\
\hline \multirow[t]{3}{*}{3} & Occupation & Employed & 60 & 43,5 \\
\hline & & Unemployed & 78 & 56,5 \\
\hline & Total & & 138 & 100 \\
\hline
\end{tabular}

Risk Factors Distribution based on DHF Cases

Table 2: Distribution of Risk Factors in the Work Area of Harapan Raya Public Health Center in Pekanbaru in 2018

\begin{tabular}{|c|c|c|c|}
\hline & Variable & Case $(n=69)$ & Control $(n=69)$ \\
\hline \multicolumn{4}{|c|}{ Knowledge } \\
\hline- & High & $57(82,6 \%)$ & $16(23,2 \%)$ \\
\hline- & Low & $12(17,4 \%)$ & $53(76,8 \%)$ \\
\hline \multicolumn{4}{|l|}{ Attitude } \\
\hline- & Bad & $38(55,1 \%)$ & $30(43,5 \%)$ \\
\hline- & Good & $31(44,9 \%)$ & $39(56,5 \%)$ \\
\hline \multicolumn{4}{|c|}{$3 \mathrm{M}$ Plus action } \\
\hline- & Bad & $59(85,5 \%)$ & $12(17,4 \%)$ \\
\hline & Good & $10(14,5 \%)$ & $57(82,6 \%)$ \\
\hline \multicolumn{4}{|c|}{ The habit of hanging clothes in the house } \\
\hline- & Yes & $39(56,5 \%)$ & $37(53,6 \%)$ \\
\hline- & No & $30(43,5 \%)$ & $32(46,4 \%)$ \\
\hline \multicolumn{4}{|c|}{ The habit of sleeping in the morning/afternoon } \\
\hline- & Yes & $49(71,0 \%)$ & $32(46,4 \%)$ \\
\hline- & No & $20(29,0 \%)$ & $37(53,6 \%)$ \\
\hline \multicolumn{4}{|c|}{ Distance between houses } \\
\hline- & $\operatorname{Near}(\leq 5 \mathrm{~m})$ & $46(66,7 \%)$ & $41(59,4 \%)$ \\
\hline- & $\operatorname{Far}(>5 \mathrm{~m})$ & $23(33,3 \%)$ & $28(40,6 \%)$ \\
\hline \multicolumn{4}{|c|}{ Water reservoir condition } \\
\hline- & Opened & $61(88,4 \%)$ & $18(26,1 \%)$ \\
\hline- & Closed & $8(11,6 \%)$ & $51(73,9 \%)$ \\
\hline \multicolumn{4}{|c|}{ Existence of larvae around the house } \\
\hline- & There are larvae & $56(81,2 \%)$ & $16(23,2 \%)$ \\
\hline- & There are no larvae & $13(18,8 \%)$ & $53(76,8 \%)$ \\
\hline \multicolumn{4}{|c|}{ Existence of water holder garbage } \\
\hline- & Exist & $57(82,6 \%)$ & $16(23,2 \%)$ \\
\hline- & Doesn't exist & $12(17,4 \%)$ & $53(76,8 \%)$ \\
\hline \multicolumn{4}{|c|}{ Existence of ornamental plants/yard } \\
\hline- & Exist & $44(63, \%)$ & $38(55,1 \%)$ \\
\hline- & Doesn't exist & $25(36,2 \%)$ & $31(44,9 \%)$ \\
\hline
\end{tabular}

Table 3: Multivariate Modeling

\begin{tabular}{|c|c|c|c|c|c|}
\hline \multirow[b]{2}{*}{ No } & \multirow[b]{2}{*}{ Variable } & \multirow[b]{2}{*}{ P-Value } & \multirow[b]{2}{*}{$O R$} & \multicolumn{2}{|c|}{ 95\% CI For EXP (B) } \\
\hline & & & & Lower & Upper \\
\hline 1 & Knowledge & 015 & 0,165 & 0,038 & 0,709 \\
\hline 2 & 3Mplus action & 017 & 6,320 & 4,062 & 10,646 \\
\hline 3 & $\begin{array}{l}\text { Habit of sleeping in the } \\
\text { morning/afternoon }\end{array}$ & ,049 & 2,058 & 1,237 & 4,726 \\
\hline 4 & Existence of garbage & 050 & 0,233 & 0,054 & 0,999 \\
\hline 5 & Condition of water reservoir & 003 & 2,136 & 1,036 & 3,510 \\
\hline 6 & Existence of larvae & ,000 & 8,103 & 6,029 & 11,369 \\
\hline
\end{tabular}


Risk Factors Related to DHF Cases

Multivariate results of risk factors for DHF cases obtained variables that were significantly related to DHF cases were the existence of larvae, 3 Plus action, water storage conditions, sleep habits in the morning and/ afternoon, the existence of garbage, and knowledge.

The most dominant variable in DHF cases was the existence of larvae with an OR value of 8,103 $(95 \% \mathrm{Cl}: 6.029-11,369)$. The result of the analysis can be seen in Table 3 .

\section{DISCUSSION}

A. The Relationship between the Existence of Larvae and DHF Cases.

Based on the result of the study, the most influential variable is the existence of larvae. This is caused by the existence of a living wiggler that makes DHF cases happen. Mosquito larvae can live in various places such as tubs, open water reservoirs, in tree holes, stone holes, leaf midribs, coconut shells, banana fronds, bamboo pieces, old tires (Ministry of Health Republic of Indonesia, 2011).

The existence of larvae can be seen by larvae surveying. If one larva is found either in a water reservoir inside the house such as in a tub, bucket, etc., or a reservoir outside the house such as tree holes, shells, etc. is considered to have found larvae in the vicinity of the house. If it was found the existence of larvae that can change into mosquitoes within 10 days, will further increase the risk of DHF disease transmission. The more the existence of larva found, the more risk of DHF transmission occurred. This is in line with the research result of Hidayah et al (2017), Rianasari et al (2016) and Arsin et al (2010) showed that there was an influence between the existence of larvae and DHF cases.

The researchers assume that there are many Aedes Aegypti larvae found in the case group because it was found so much garbage that can hold water in a large number of DHF sufferers. One of them is the existence of used tires that are flooded by water with Aedes Aegypti inside found around the DHF sufferer's house. If the used tire is not immediately recycled or cleaned by the respondent, the mosquitoes will grow up and be at risk for DHF transmission.

\section{B. The Relationship between $3 \mathrm{M}$ Plus Actions} and DHF Cases.

$3 \mathrm{M}$ Plus actions affect the DHF cases because the eradication of mosquito nests can be done through $3 \mathrm{M}$ Plus activities. Considering that there is no vaccine to prevent Dengue Hemorrhagic Dengue until now, so the actions to eradicate DHF should be focused on the infector (Aedes Aegypti), in addition to early vigilance against DHF cases to limit the number of morbidity and mortality. Although spraying mosquitoes by using insecticides is done, but if the mosquito's larvae are still alive, new mosquitoes will grow up then they transmit DHF disease (Suyasa, 2008).

What is meant by $3 M$ includes: Draining the tub regularly at least once a week, replacing water in a flower vase, drink for birds or other water reservoirs regularly every less than one week, closing tightly water reservoirs. Using or recycling used cans, plastics, used tires, and other items that can hold rainwater so that it does not become a mosquito nest (Susanto, 2007).

Furthermore, the pluses are: using mosquito nets, installing wire nets, using mosquito repellent, taking care of larvae eating fish, closing bamboo cut holes, being aware of all objects and plants that can hold water (Surtiretna, 2009). Drainage of water reservoirs needs to be done regularly at least once a week so that mosquitoes cannot breed. In addition to draining the water reservoirs, the $3 \mathrm{M}$ implementation must also consider the availability of water storage covers to suppress the number of mosquitoes that perch on the water reservoir, it will become a breeding medium for Aedes Aegypti mosquitoes. The availability of water reservoir covers including drums and buckets. And the last is burying / recycling used goods so that they cannot collect rainwater and become a place for mosquitoes to lay eggs (Fakhriadi et al, 2015).

If we do not drain the water reservoir at least once a week, do not close the water reservoir, do not use/recycle used goods will be at risk to occur DHF cases. Based on the research of Khan et al (2018), Carundeng et al (2015) dan Arellano et al (2015) there is an influence between the actions of draining the water reservoirs, burying used goods with the DHF cases. Furthermore, the research of Lumingas et al (2017) also states that there is a relationship between the practice of depleting the landfills, the practice of closing the landfills, and burying the used goods with DHF cases in the working area of Tanawangko Public Health Center.

Based on the research of Adhariyanti (2015), there are risk factors between $3 \mathrm{M}$ Plus action and Dengue Hemorrhagic Fever (DHF) cases. According to Nasriati (2012), there is an influence between $3 \mathrm{M}$ Plus behavior on the risk of DHF cases in the working area of East Labuhanhaji Public Health Center, South Aceh Regency.

The researchers found that the respondents consider if it is enough to do only one of $3 \mathrm{M}$ Plus actions and feel they have prevented the occurrence of DHF. Many respondents still do not understand the benefits of $3 \mathrm{M}$ Plus, it can be 
proven by the number of respondents in the case group who has low knowledge, around $82,6 \%$ or 57 people of 69 respondents. As a consequence, there are so many respondents do not carry out $3 \mathrm{M}$ Plus such as draining the tub to save water, do not close the water reservoir to collect rainwater that can be used to water the plants and then be used for other purposes, do not utilize/recycle used items immediately because they want to collect the used items as many as possible before selling them to the garbage picker whereas the range of time is so long. Then, most of the respondents' house has been put cement, so there is no more place for burying used goods. Some so many people still do not practice $3 \mathrm{M}$ Plus because they do not understand and think it is not too important to do the $3 \mathrm{M}$ Plus.

\section{The Relationship between the Condition of the Water Reservoir and the DHF Cases.}

The condition of the water reservoir influences the incidence of DHF disease. The main breeding ground for Aedes Aegypti mosquitoes is a water reservoir inside or around the house or public places. The breeding place of mosquitos is a puddle of water in a spot or water reservoir. One of the causes of the water reservoir becomes Aedes Aegypti mosquito breeding place is that water reservoirs are not closed (Pengestu, 2009).

The breeding of mosquitoes from eggs into adult mosquitoes takes 10 days so that the condition of the unclosed water reservoir allows mosquitoes to breed which causes increased mosquito density. If the density of mosquitoes increased, the risk of suffering DHF disease will increase too. According to the research of Widjaja (2011), it shows that people who have an unclosed water reservoir get a risk of 1.273 times more affected by DHF than people who have a closed water reservoir $(p<0,05)$.

Based on the researcher's observation results shown that the respondent's water reservoir affects the incidence of DHF because most of the conditions found in the water reservoirs at the house of the case group respondents are mostly open, there are $88,4 \%$ of houses or around 61 houses. If this condition is permitted, it will be easy for mosquitoes to lay eggs and breed in these water reservoirs.

D. The Relationship between Morning and or Afternoon Sleep Habits with the DHF Cases.

The habits of sleeping in the morning and or afternoon in this research affect the incidence of DHF. Usually, female mosquitoes look for prey during the day. Biting activities usually start from morning to evening with two peak activities between 9 to $10 \mathrm{a} . \mathrm{m}$. and 4 to $5 \mathrm{p} . \mathrm{m}$. Aedes aegypti has the habit of sucking blood repeatedly in one gonotrophic cycle to fill his stomach with blood. Thus, this mosquito is very effective as a contagious DHF disease $(\mathrm{MOH}, 2005)$.
The habit of sleeping in the morning or afternoon which is usually done by children has a detrimental effect on health. The habit of the Aedes aegypti mosquito is biting in the morning until the afternoon when the occupants of the house take a nap that increases the risk for DHF disease.

Based on the research of Amrieds et al (2016), there is a relationship between the habit of sleeping in the morning until the afternoon with the DHF cases in the Village of November 19, Wundulako District, Kolaka Regency in 2016. In line with the research of Abdullah et al (2010), the habit of sleeping from morning to afternoon is related to the DHF cases in Jeneponto Regency.

The researchers' observation results are seen from the habits of respondents in the group of cases accustomed to sleeping in the morning and or during the day, there are $71 \%$ or 49 respondents when compared to the control group who are only accustomed to taking a nap around $46,4 \%$. Perhaps, it is because the respondents are accustomed to hanging the clothes inside the house so that mosquitoes easily rest in the hanging clothes and biting at any time, usually at 8 to 11 a.m. and 2 to 5 p.m. the mosquito will react easily because the prey is sleeping. This is also related to the number of larvae found in the respondent's house in the case group.

\section{E. The Relationship between the Existence of Garbage and the DHF Cases.}

In this study, the existence of garbage influences the incidence of DHF cases. Tires, bottles, plastics, and other items that can hold water are possible facilities for mosquitoes as the breeding places. The more used goods (garbage) that can hold water, the more places for mosquitoes to lay eggs and breed, so that the risk of DHF cases also increased (Widodo, 2012).

Although only one used item (garbage) is found that can hold water, it can assume that there is already a waste that can become a breeding place for mosquitoes. If the used items that can hold water are found, so there are more mosquitoes will breed around the house so that more vectors can spread the dengue virus and increase the risk for the incidence of DHF disease.

According to the research of Hasan (2008) in Bandar Lampung, the existence of garbage that can hold water around the house has twice as risky for DHF. Based on Wahyudi's research (2015), it is known that there is a significant relationship between the existence of garbage that can hold water and the incidence of DHF.

The amount of garbage that can hold water found around the houses of the case respondent is very risky for the incidence of DHF. The researchers found used tires, plastics to drink waste around 
the respondent's house in the presence of Aedes aegypti mosquitoes larvae which if it is not treated immediately (cleaned), will become adult mosquitoes that will be able to transmit DHF if they have bitten a DHF sufferer.

\section{F. The Relationship between Knowledge and DHF Cases.}

According to the research result, knowledge affects DHF cases. Knowledge is the knowing result of someone sensing a certain object. The sensing occurs through the human senses, they are the sense of sight, hearing, smell, taste, and touch. Some of the human knowledge is obtained through the eyes and ears. Knowledge of cognitive is a very important domain for the information of one's actions (overt behavior), knowledge itself is influenced by the level of education, where health knowledge will affect the behavior as a result of the medium-term (intermediate impact) of education of health (Notoatmodjo, 2012). Furthermore, health behavior will affect the improvement of public health indicators as an output of education.

According to the research of Purnama in 2013, there is a relationship between knowledge and the Dengue Hemorrhagic Fever (DHF) cases with the value of $p=0,004(O R=2,72)$ while Yulianto's research (2013) states that there is a relationship between knowledge and the Dengue Hemorrhagic Fever (DHF) cases with the value of $p=0,000(O R=$ 10,7).

Based on the researchers' observation results the level of public knowledge is still low on the occurrence of Dengue Hemorrhagic Fever (DHF) because respondents give a lack of participation in attending counseling by health workers about DHF. It is caused by the respondents' level of education that tends to differ in the same range, which is the level of high school. High school education has been categorized as high education while the knowledge gained in high school does not exist about overall DHF control. So, even though many respondents are highly educated, their knowledge about DHF is not certainly high. Besides that, it is seen from the lack of insight and information obtained about Dengue Hemorrhagic Fever (DHF) disease so that they do not know about the causes, signs, and prevention of Dengue Hemorrhagic Fever (DHF). Therefore, there is an increase in dengue fever that continues to increase every year.

\section{CONCLUSION}

Six variables that influence the DHF cases, were: the existence of larvae, the action of $3 \mathrm{M}$ Plus, the condition of the water reservoir, the habit of sleeping in the morning and afternoon, the existence of garbage, and knowledge. The most dominant variable was the existence of larvae. Four variables did not affect the DHF cases, they were: attitude, the distance among houses, the habit of hanging clothes, and the existence of yard/ornamental plants. The community is expected to be able to recycle waste (garbage that has the potential to hold water). The health workers are expected to give training on how to recycle the garbage properly.

\section{ACKNOWLEDGMENT}

I thankful to my promoters and co-promoters I and II, who have provided so much support so that this article is done

\section{REFERENCES}

1. Abdullah A Z, Nawi R, Sibe A. (2010). Risk Factors for Dengue Hemorrhagic Fever Occurrence in Tempe District, Wajo Regency 2009. (Online). MKMI Journal. Vol. 6 No. 4

2. Adhariyanti, Y. (2015). Case Study Analysis of Dengue Hemorrhagic Fever (DHF) in the Harapan Raya Pekanbaru Community Health Center in 2012-2014. Thesis. STIKes Hang Tuah Pekanbaru, Pekanbaru.

3. Amrieds E, et al. (2016). Factors Related to the Occurrence of Dengue Hemorrhagic Fever (DHF) in Kelurahan 19 November Wundulako District, Kolaka Regency in 2016. Scientific Journal of Public Health Students. Vol. 1 No. 3.

4. Arellano, C. Castro, L. Rolando, E. Coraventas, D. Emst, KC. Hayden, M, and Castro, PR. (2015). Knowledge and Beliefs about Dengue Transmission and Their Relationship with Prevention Practices in Hermosillo, Sonora. Frontiers in Public Health Vol. 3, June 2015.

5. Arsin A, Syafar M, Abbas A. (2010). Factors Related to the Occurrence of Dengue Fever (DHF) in KAB. Jeneponto, (Online), Journal of MKMI. Vol. 6 No. 2,

6. Carundeng M, et al. (2015). Analysis of Factors Related to the Occurrence of Dengue Hemorrhagic Fever in Kotogobagu City Gogagoman Health Center. Journal of Public Health. Vol. 4 No. 1

7. Ministry of Health of the Republic of Indonesia. (2005). Prevention and Eradication of Dengue Fever in Indonesia. Jakarta.

8. Pekanbaru City Health Service. (2017). Data on Dengue Hemorrhagic Fever Cases All Pekanbaru City Health Center: Pekanbaru. 
9. Riau Provincial Health Office. (2017). Dengue Hemorrhagic Fever Case Data: Pekanbaru.

10. Fakhriadi R, et al. (2015). Risk Factors for Dengue Hemorrhagic Fever in the Work Area of the Guntung Paying Health Center in Banjarbaru City. Journal of Indonesian Public Health Publications. Vol. 2 No. 1

11. Hasan A. (2008). Correlation between Mosquito Nest Eradication Behavior and the Occurrence of Dengue Fever in Bandar Lampung City. National Public Health Journal. Vol. 2 No. 2

12. Hidayah, N. Iskandar \& Abidin, Z. (2017). Prevention Of Dengue Hemorrhagic Fever (DHF) Associated with the Aedes Aegypti Larvae Presence-Based on the Type of Water Source. The Journal of Tropical Life Science, Vol. 7, No. 2, PP 115-120, April 2017.

13. Khan, J. Khan, I. Gaffar, A \& Khalid, B. (2018). Epidemiological Trends and Risk Factors Associated with Dengue Disease in Pakistan (1989-2014): a Systematic Literature Search and Analysis. BMC Public Health.

14. Ministry of Health of the Republic of Indonesia. (2011). Dengue Hemorrhagic Fever Control Module: Jakarta.

15. Ministry of Health of the Republic of Indonesia. (2016). Circular of Exterminating the Eradication of the $3 \mathrm{M}$ Plus Mosquito Nest with the One Home One Jumantik Movement: Jakarta.

16. Lemeshow. 1997. Large Samples in Health Research. Jogjakarta. Gadjah Mada University Press.

17. Lumingas E, et al. (2017). Factors Related to the Occurrence of Dengue Fever in the Work Area of Tanawangko Health Center. Journal of Health Media. Vol. 9 No. 3.

18. Nasriati, Afriza T. (2012). Influence of Community Behavior in 3M Plus Against Risk of Occurrence of Dengue Fever in the Work Area of Labuhanhaji Timur Health Center, South Aceh District in 2012. Journal of UUI.

19. Notoatmodjo, S. (2012). Health Research Methodology. Jakarta: Rineka Cipta.

20. Pangestu, Harmany N, Hasyimi M. (2009). Recent Places Preferred for Breeding Aedes sp. (online). Health Research and Development Media. Vol. 19 No. 2.
21. Purnama et al (2013). Knowledge, Attitudes, and Behavior in the Eradication of Mosquito Nest against Dengue Infection in South Denpasar District, Denpasar City, Bali. Arc-Com. Health - June 2013 ISSN: 9772302139009. Vol. 2 No. 1: 20-27.

22. Rianasari, Suhartono, \& Dharminto. (2016). The Relationship Between Physical and Behavioral Environmental Risk Factors with the Occurrence of Dengue Hemorrhagic Fever in Mustikajaya Village, Bekasi City. Journal of Public Health, Vol. 4, number 5.

23. Surtirena, N. (2009). Beware of Dengue Fever. Bandung: PT Kiblat Buku Utama.

24. Suyasa et al., 2008. Relationship between Environmental Factors and Community Behavior with the Existence of Dengue Hemorrhagic Fever Vector. Economic Journal. Vol. 3. No.1 May 2008: 1-6.

25. Wahyudi, H. (2015). Factors Affecting the High Incidence of Dengue Fever (DHF) in the Work Area of the Mandau District Health Center in Bengkalis Regency in 2015. Thesis. STIKes Hang Tuah Pekanbaru, Pekanbaru.

26. Widjaja J. (2011). The Presence of Containers as a Risk Factor for Transmission of Dengue Hemorrhagic Fever in Palu City, Central Sulawesi. (Online), Vol. 3 No. 2

27. Widodo, N. (2012). Factors Related to the Occurrence of Dengue Haemorrhagic Fever in Mataram City, West Nusa Tenggara Province, 2012. Universitas Indonesia: Thesis.

28. Yulianto, B \& Febriana (2013). Factors Related to the Occurrence of Dengue Hemorrhagic Fever (DHF) in Selatpanjang Health Center, Kepulauan Meranti District. Journal of Community Health, Vol. 2, No. 3, November 2013 